\title{
Degradation and Reprocessing of Heparan Sulphate in Recycling Glypican (Heparan Sulphate Proteoglycan)
}

\author{
再循環するグリピカン（ヘパラン硫酸プロテオグリカン）における \\ ヘパラン硫酸の分解と再生
}

\author{
Fransson, Lars-Åke*; Belting, Mattias; Edgren, Gudrun; Jönsson, Mats; \\ Mani, Katrin; Schmidtchen, Artur; and Wiik, Pernilla \\ Department of Cell and Molecular Biology, Section of Cell and Matrix Biology, Lund University, POB 94, \\ S-221 00 Lund, Sweden FAX: 46-46-222 3128, E-mail: Lars-Ake.Fransson@ medkem.lu.se
}

Key Words : caveolae, glypican, nitric oxide, recycling, spermine

\begin{abstract}
The structure of the heparan sulphate-carrying proteoglycan glypican is briefly reviewed. The mode of membraneattachment provides means of apical sorting in polarized cells and potential concentration to caveolae, as well as several different cleavage points resulting in release from its lipid anchor. The heparan sulphate side-chains are degraded in steps involving endoglycosidic cleavage to form large oligosaccharides followed by terminal exo-degradation. Data supporting internalization and partial degradation in endosomes, followed by recycling of the intact core protein back to the cell-surface are specifically reviewed. The means of degradation (enzymatic $v s$. non-enzymatic) and re-processing by re-synthesis of heparan sulphate on remaining core-protein stubs are discussed. Several investigations have provided evidence that cell-surface heparan sulphate proteoglycans play a role in the internalization of growth factors, polyamine-DNA complexes, viruses and microbes. In polarized cells, recycling heparan sulphate proteoglycans may be the transport vehicle in transcytosis.
\end{abstract}

\section{A. Introduction}

Heparan sulphate (HS) is a polymer of the basic repeating disaccharide unit -4GlcUA $\beta 1-4 \mathrm{GlcNAc} \alpha 1$ - that is variously modified by exhange of $N$-acetyl for $N$-sulphate, by C-5 epimerization of GlcUA to IdoUA, and by ester sulphation at $\mathrm{C}$ 6 of the amino sugar and at C-2 of the hexuronic acids as described in detail elsewhere in this issue of TIGG. It has been known since Kraemer's first observations that HS is a common cell-surface component of adherent cells and that it is continually released/degraded and resynthesized during the cell-cycle (1). Cell-surface HS-chains are generally covalently attached to proteins that are bound to the plasma membrane. The types and characteristic features of the various proteoglycan (PG) core proteins that can carry HS are presented in other reviews of this

* To whom correspondence should be addressed
要 約

ヘパラン硫酸側鎖を持つプロテオグリカンの一種であるグ リピカンの構造を概説する。グリピカンはその膜結合様式によ り極性細胞の頂面に局在したり、小胞に高濃度で移行すること ができる。さらにこの膜結合様式により、グリピカンは特異的 酵素により脂質アンカーから遊離することも知られている。へ パラン硫酸側鎖はまず、エンドグリコシド分解を受け、大きめ のオリゴ糖が生成される。引き続き、このオリゴ糖は末端基の エクソ分解を受けることになる。本論では特に、細胞内への取 り込み、エンドソムでの部分的分解、その後のコアタンパク質 の再循環と細胞表面への復帰を支持するデー夕を紹介する。ま た、糖鎖分解 (酵素的そして非酵素的) や残ったコアタンパク 質の切り株への糖鎖再合成の意義を記述していく。何人かの研 究者は、細胞表面へパラン硫酸プロテオグリカンは増殖因子、 ポリアミン-DNA 複合体、ウイルス、微生物の細胞内取り込み のための役割を果たしていることの証明を与えた。極性細胞で は、へパラン硫酸プロテオグリカンの再循環機構がトランスサ イトーシス (transcytosis)に扔ける運搬媒体としての役割を果た していると考えられている。

\section{A.はじめに}

ヘパラン硫酸 (HS) は塩基性二糖体単位 (4GlcUA $\beta 1$ 4GlcNAc $\alpha 1$ 1-) の繰り返し構造からなる高分子で、この特集号 の他のレビューでも述べられているように、 $N$-アセチル基の $N$ 硫酸基への置換、GlcUA の IdoUAへのC5-エピマー化、アミノ 糖のC-6 位やウロン酸の C-2 位のエステル硫酸化などの様々な 修飾がなされている。Kraemerらの最初の記述以来、HS は接着 細胞表面に普遍の構成要素であり、細胞周期を通して絶え間な く、遊離/分解、再合成が行われている (1)。細胞表面HS鎖は、 通常細胞膜と結合しているコアタンパク質と共有的に結合して いる。HS 側鎖を持つ様々なプロテオグリカンコアタンパク質の 分類や特徴は、この特集号の他のレビューに記述されている。 多くの場合このコアタンパク質は、脂質二重層を貫通した踈水 


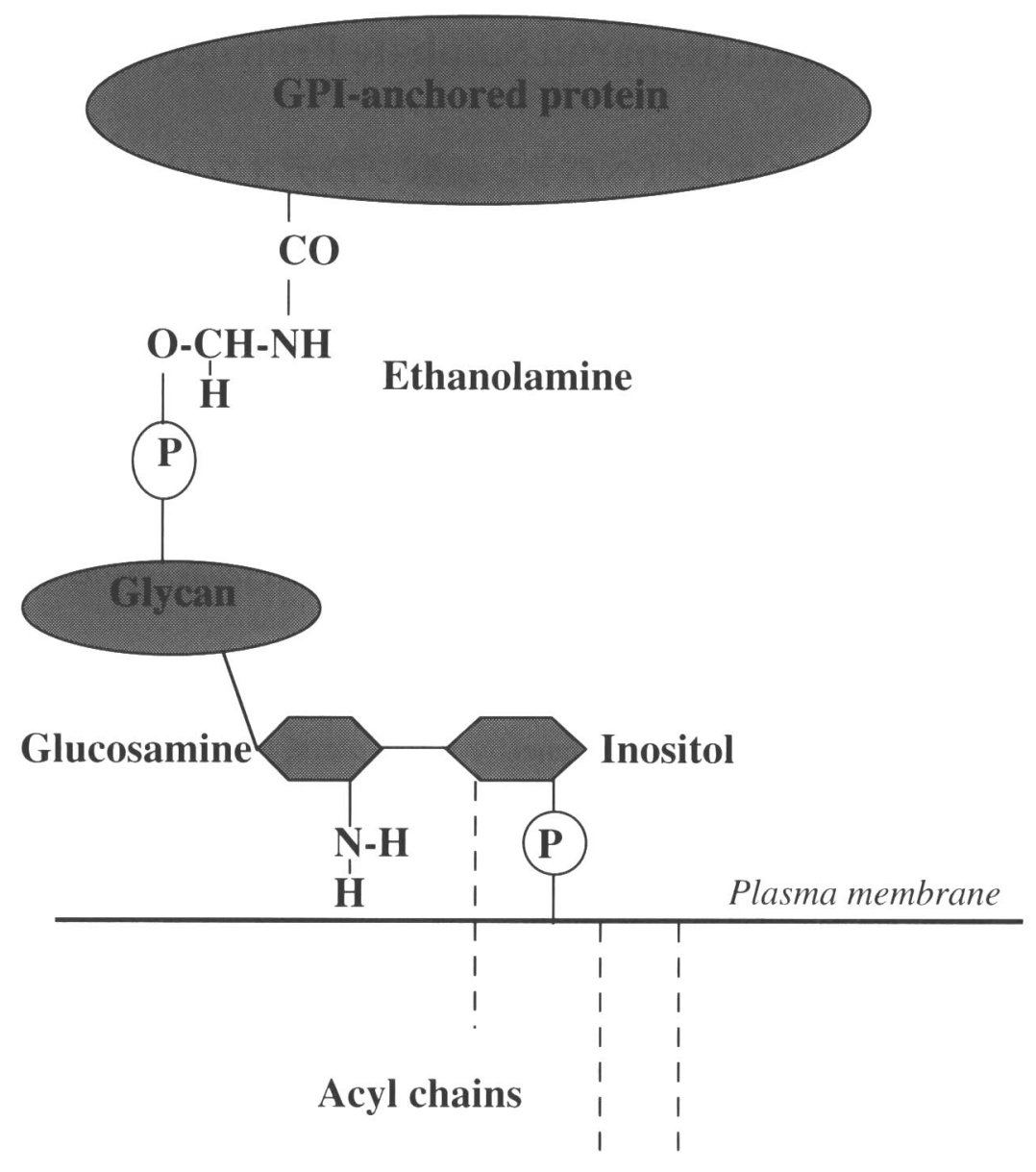

Fig. 1. Structure of a typical GPI-anchored protein.

issue. In many cases the core proteins are typical membrane proteins with hydrophobic peptide segments that penetrate the lipid bilayer.

The first indication that HSPG can be bound to the plasma membrane through a phosphatidylinositol (PtdIns) moiety covalently linked to the core protein was presented in a study by Ishihara et al. (2). It was demonstrated that HSPG of a rat hepatocyte cell line could be released by treatment with PtdIns-specific phospholipase C (PI-PLC). The released HSPG with the Ins-P moiety still attached to the core protein was then internalized via a receptor that recognized this moiety. PtdInsattached HSPG were later demonstrated in Schwann cells (3), ovarian granulosa cells (4) and fibroblasts (5). It had been known since the late 1970 s that many cell-surface proteins could be attached in this manner and today a large number of socalled glycosyl-PtdIns (GPI)-anchored proteins are known (for review, see ref. 6). The principal structure of a GPI-anchor is shown in Fig. 1.

David's group performed the molecular cloning and sequence determination of the GPI-anchored HSPG from fibroblasts and named it glypican (7). The PG can be depicted as in
性ペプチドドメインを有する典型的な膜型タンパク質である。

石原らが発表した研究は、HSPGにはコアタンパク質と結 合したホスファチジルイノシトール (PtdIns)を介して細胞膜と 結合している形態があることを最初に示した (2)。その研究は、 ラット肝細胞株の作る HSPGは PtdIns 特異ホスホライペース C (PI-PLC) により遊離させることができることを示した。この遊 離したHSPGはまだコアタンパク質に結合したままのIns-P部 位をもち、次にこのIns-P部位を認識するレセプターを介して細 胞内に取り込まれる。その後、PtdIns-結合 HSPG はシュワン細 胞 (3)、卵巣顆粒細胞 (4)、線維芽細胞 (5)にも見出されている。 1970代後半からたくさんの細胞表面タンパク質がこれと同じ形 態で細胞膜に結合していることが明らかになり、今日では多く のグリコシル -PtdIns (GPI) - 結合タンパク質として知られてい る(総説、文献6)。GPI-結合の主要な構造は図1に示されてい る。

デイビッドらのグループは線維芽細胞から GPI-結合HSPG の分子クローニングとDNA配列決定を行い、この分子をグリピ カンと命名した (7)。図2に示したように、この PGはN-末端部 


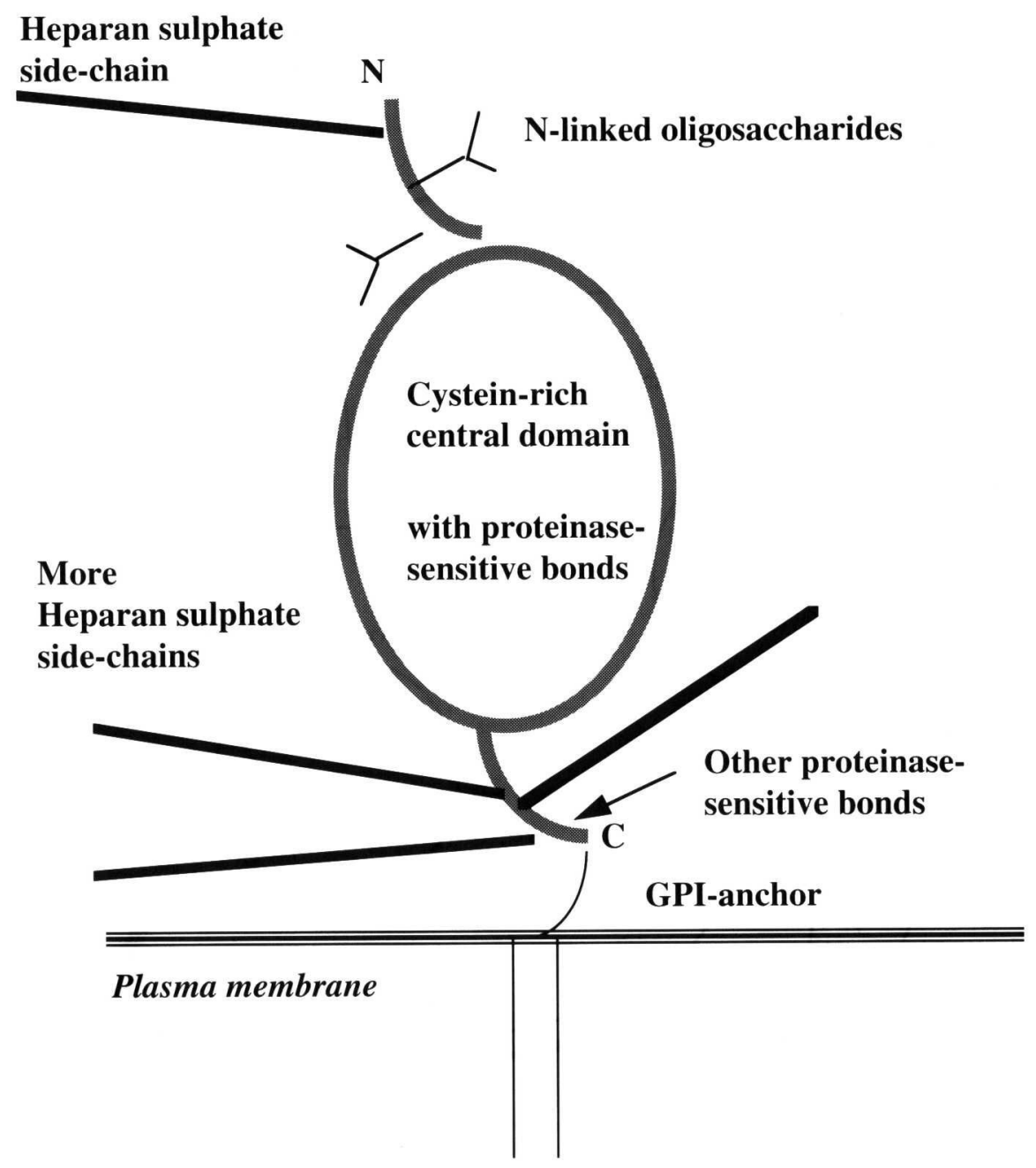

Fig. 2. Model of a prototype glypican proteoglycan.

Fig. 2 with an N-terminal portion containing one potential HSattachment site and two $\mathrm{N}$-linked oligosaccharide sites, a central cysteine-rich, probably globular domain, and a C-terminal part that contains three more HS-sites and is connected to the GPI-anchor. It is not known to what extent the four potential HS-sites are utilized in individual cases. The glypican family has now several different members as described elsewhere.

The role of the GPI-anchor for targetting and membrane dynamics has been much debated. Simons and collaborators have proposed (for review, see ref. 8) that the dynamic clustering of sphingolipids and cholesterol in cell membranes serves as sorting centres for proteins destined for delivery to the apical membrane of polarised cells, such as epithelial and endothelial cells. It has been demonstrated that GPI-anchored proteins interact with these membrane patches and use their lipid anchors as apical sorting determinants (9). David's group (10) have recently obtained the somewhat surprising result that most of the glypican PG was located to the basolateral surface of polarized
分に一つの可能な HS 結合部位と二つの $\mathrm{N}$-結合オリゴ糖結合部 位をもち、中央には球状と思われるシステインに富んだドメイ ンがある。そのC-末端部分はさらに三つのHS 結合部位を含み、 GPI- アンカーに結合している。個々のケースでこの四つのHS 結合部位のいくつが使われているかは明らかではない。グリピ カンファミリーは現在、七つの異なるメンバーが知られている。 標的化や膜動態での GPI- アンカーの役割が多く議論され た。サイモンらは、細胞膜でのスフィンゴ脂質やコレステロー ルの動的クラスタリングは上皮や内皮細胞のような極性細胞の 頂部へ指向されるタンパク質の区分けセンターとして働くこと を提案した (総説、8)。GPI- アンカータンパク質はこれらの膜 の一部と相互作用し、この脂質アンカーは頂部指向の決定因子 として働く事が示されている(9)。デイビッドのグループは最近 少々驚くべき結果を発表している (10)。すなわち、グリピカン PG のほとんどは極性上皮細胞の基底外側に局在しており、HS 結合部位変異体の導入実験で、頂部指向性はC-末端付近の HS- 


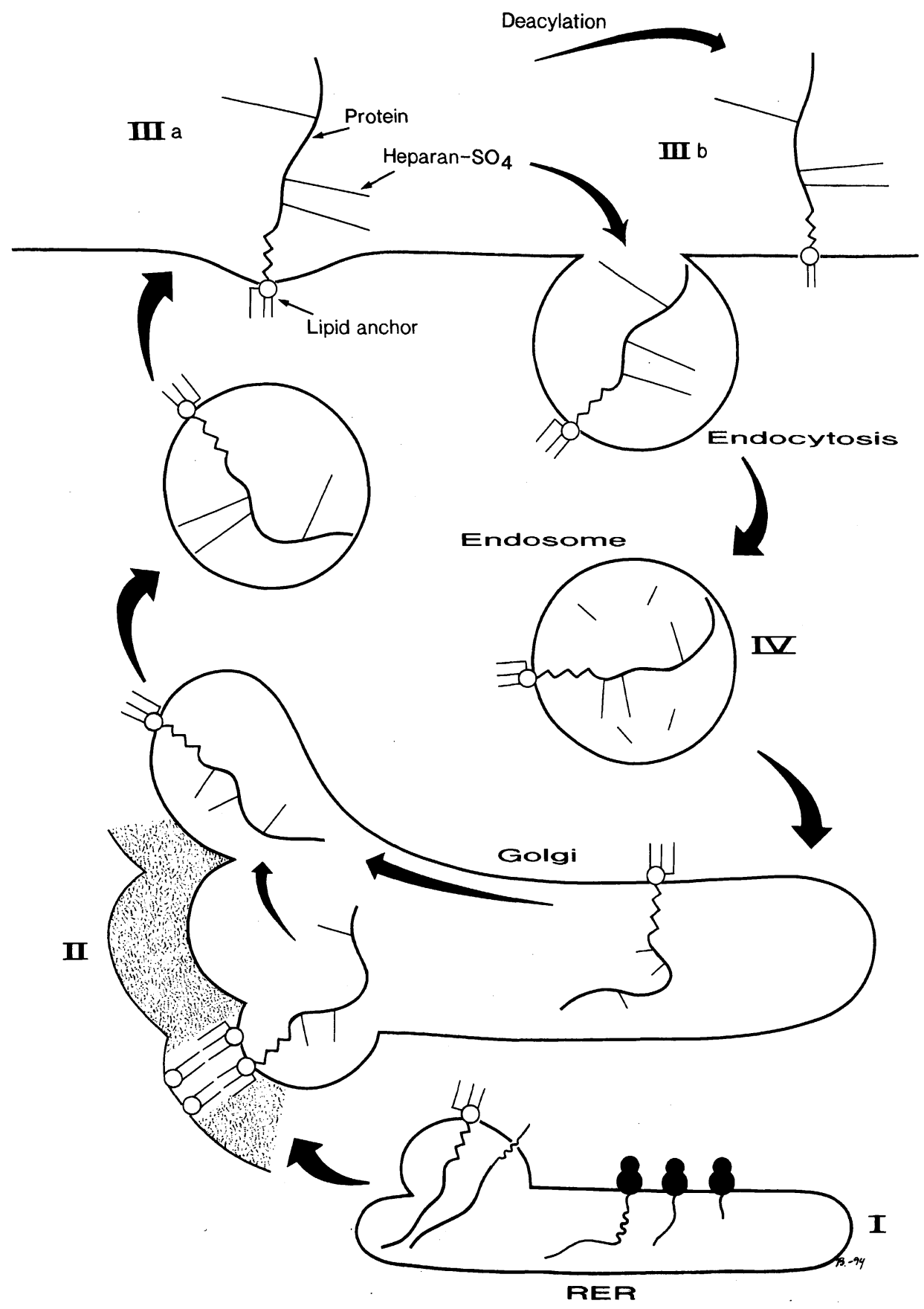

Fig. 3. Model for the synthesis, secretion, endocytosis and recycling of glypican in fibroblasts. Site I, Biosynthesis of the core protein and transfer to the GPI-anchor; Site II, Assembly of HS chains; Site III, At the cell-surface with (a) or without (b) inositol acylation; Site IV, Partial degradation of HS side-chains.

epithelial cells. Transfection experiments with HS-site mutated forms of glypican showed that apical targetting increased markm edly upon removal of HS-sites located near the C-terminal. When all three of these sites were removed glypican core protein was exclusively directed to the apical surface.

Anderson and collaborators $(11,12)$ showed that GPIanchored proteins, along with sphingolipids and cholesterol, are enriched in specific cell-surface structures called caveolae
結合部位を除くことで顕著に増加することを示した。この三つ の HS 結合部位をすべて除くと、グリピカンコアタンパク質は もっぱら頂部表面に指向された。

$$
\text { アンダーソンらは、GPI- アンカータンパク質はスフィンゴ }
$$
脂質やコレステロールとともに小胞 (caveolae) と呼ばれる細胞 表面構造体 (細胞膜陥入腔／小胞)に集中していることを示した (11、12)。これらの構造体では、レセプターや酵素そして相当す 
Trends in Glycoscience and Glycotechnology Vol.10 No.52 (March 1998) pp.81-94

(or plasmalemmal invaginations/vesicles). In these structures receptors or enzymes as well as carriers for corresponding ligands/products come close together. This arrangement serves to concentrate ligands or generate products in proximity to the carrier, thereby creating a high local concentration gradient for transport into the cell. It is not known whether glypican can reside in caveolae, nor if it can be degraded therein.

\section{B. Degradation of Cell-Surface Heparan Sulphate}

Heparan sulphate carried by glypican can be released from the cell surface in several different ways. Cleavage by PtdIns-specific phospholipases of type C releases the whole PG with the terminal phosphate group of inositol still attached (see Fig. 1). Proteolytic cleavage would release the entire ectodomain with its HS-chains (see Fig. 2). The PG may be shed into the extracellular environment or taken up by endocytosis (see Fig. 3). Yanagishita (13) found that glypican of rat ovarian granulosa cells was mainly endocytosed and rapidly degraded without generating recognizable intermediates. However, partial degradation of HS-chains has been demonstrated in many types of cell cultures (14-19). Oligosaccharides of approx. $\mathrm{M}_{\mathrm{r}} 7 \mathrm{kDa}$ and generated by degradation of cell-surface HSPG were first detected in endosome-like fractions of liver homogenates $(14,15)$. As the fragments carried GlcUA at the reducing terminus, they had been generated by the action of an endoglucuronidase, similar to that involved in degradation of heparin in mast cells. The endoglucuronidase probably acts in the low-sulphated, less-modified regions of the HS-chain. This enzymatic activity has also been detected in tumour cells (16). It has been demonstrated that release of HS-chain fragments can occur without concomitant destruction of the core protein (17).

The structures of the HS-fragments released have been compared with those of HS-chains in the parent cell-surface PG. Hoving et al. (18) found that the degradation products were less sulphated and had a more heterogeneous charge distribution than PG side-chains. They also found a large proportion of $N$-sulphated GlcN at the reducing terminus of the fragments suggesting cleavage by an endohexosaminidase. Schmidtchen and Fransson (19) obtained HS-oligosaccharides with a high proportion of sulphated IdoUA near their respective termini. Curiously, prolonged extraction of cells with Triton X-100 at $4^{\circ} \mathrm{C}$ in the presence of proteinase inhibitors resulted in further degradation. The process appeared to occur in steps as distinct size-pools of HS-fragments (30-40 kDa, approx. $17 \mathrm{kDa}$ and $7-10 \mathrm{kDa}$ ) were obtained. Taken together, these results indicate that cleavage can take place also in the highly sulphated and modified regions of HS which are often distributed in a regular fashion along the chain (see other reviews in this volume). In a very recent study, Bai et al. (20) provided evidence that 2-Osulphation of uronic acids is critical for the generation of inter-
るリガンドや生成物が集積してくる。その結果、キャリヤの近 くにリガンドや生成物質の濃縮が起こり、細胞内へ伝搬するた めの濃度勾配が生じる。ただし、グリピカンがその小胞に存在 するのか、そしてそこで分解されるのかどうかについてはまだ 知られていない。

\section{B. 細胞表面ヘパラン硫酸の分解}

グリピカンの持つヘパラン硫酸はいくつかの方法で細胞表 面から遊離させることができる。PtdIns 特異ホスホリパーゼ C 型での分解は、イノシトールの末端リン酸基を持ったPG全体を 遊離する (図1)。タンパク分解酵素はHS 鎖を持つ細胞外ドメイ ン全体を遊離させるであろう (図 2)。そのPG 細胞外へ分泌さ れ、再び細胞内へエンドサイトーシスされる(図3)。柳下らは、 ラット卵巣顆粒細胞のグリピカンは主にエンドサイトーシスさ れ、検知できる中間体を生成することなく、迅速に分解される ことを見出した (13)。しかし、HS鎖の部分的分解は多くの種類 の培養細胞により見出されている(14-19)。細胞表面HSPGの分 解により生成した分子量約 $7 \mathrm{kDa}$ のオリゴ糖が、まず肝臓ホモ ジナートのエンドソム様画分から検出された (14、15)。還元末 端にはGlcUAを持つことから、それらはエンドグルクロニダー ゼの作用で生成されたことがわかる。これらは、肥満細胞での ヘパリンの分解物に含まれるものと同じである。エンドグルク ロニダーゼは、おそらく HS 鎖の低硫酸化、低修飾領域に作用す るものと考えられる。この酵素活性はまた、腫瘍細胞からも検 出されている (16)。HS 鎖断片の遊離はコアタンパク質の分解 を伴わずに起こることが示されている (17)。

遊離した HS 断片の構造が元の細胞表面 PG の HS 側鎖のも のと比較された。ホビングらは、分解生成物は元のHS側鎖より も硫酸化度が低く、より不均一な電荷分布を持っていることを 見出した (18)。彼らはまた、糖鎖断片の還元末端は $N$ - 硫酸化 GlcNの比率が大きいことから、この分解がエンドヘキソースア ミニダーゼの作用であることをを示唆した。シュミッチェンと フランソンは、それぞれの末端に高比率で硫酸化IdoUAを持つ 糖鎖断片を得た (19)。面白いことに、タンパク分解酵素阻害剤

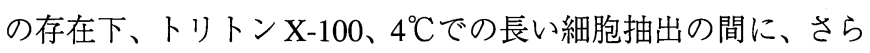
にHS 断片が分解されていく。この作用は段階的に起こるよう で、別個の HS 断片が得られる $(30-40 \mathrm{kDa}$ 、約 $17 \mathrm{kDa}$ 、約 7-10 $\mathrm{kDa})$ 。これらの結果から考えて、この分解反応はHS 糖鎖にしば しば規則正しく分布する高硫酸化、修飾領域に起きるというこ とができょう(この本の他のレビュー参照)。つい最近バイらは、 ウロン酸の 2-O- 硫酸は、糖鎖のリソゾームによる分解ではな 
Trends in Glycoscience and Glycotechnology Vol.10 No.52 (March 1998) pp.81-94

mediate-size HS-oligosaccharides but not for the overall lysosomal catabolism of the chains.

In the course of studies on biosynthesis of PG by human vascular endothelial cells (HUVEC) grown in the presence of whole-blood serum, we observed $(21,22)$ an autodegradation of the radiolabelled HSPG. The degradation took place during extraction with Triton X-100 at $4^{\circ} \mathrm{C}$ generating HS-fragments of $M_{r} 10-20 \mathrm{kDa}$. The degradation did not take place if heparin was added to the extraction solvent, if $4 \mathrm{M}$ guanidine was used as extractant, or if the cells had been grown in the presence of plasma-derived serum (22). Increased temperature, growth in unsealed flasks or dilution of the extraction medium prevented or diminished generation of HS-oligosaccharides. Exogeneously added $\mathrm{HS}$ was also degraded by incubation at $4^{\circ} \mathrm{C}$ in small volumes of extracts of HUVEC that had been grown in the presence of whole serum. Degradation was again inhibited by heparin but also by pre-treatment of the cells with trypsin. Initially, we believed that a cell-surface, serum-stimulated, protease-sensitive endoheparanase, juxtapositioned to the PG substrate in some rigid membrane-structure, was responsible for the degradation. Raising the temperature and diluting the extract might have caused dispersion of the involved components. The effects of guanidine and heparin was ascribed to denaturation and inhibition, respectively, of an enzyme. The need for tightly sealed flasks remained unexplicable, until we realized that gaseous signal molecules exist and that non-enzymatic processes could result in degradation of HS.

Vascular endothelial cells produce nitric oxide (NO) which can diffuse to neighbouring smooth muscle cells and initiate relaxation and vasodilation (for reviews, see refs. 23, 24). NO is generated from arginine in a reaction catalyzed by NOsynthase and has a short life-time. NO is taken up by heme groups but it is also consumed by oxidation to nitrite $\left(\mathrm{NO}_{2}^{-}\right)$. It has been known for a long time (25-27) that nitrous acid $\left(\mathrm{HNO}_{2}\right)$ can degrade $\mathrm{HS}$. At $\mathrm{pH}$ values around 4, there is preferential cleavage of the hexosaminidic bond involving GlcN with an unsubstituted amino group, whereas bonds involving $\mathrm{N}$ sulphated glucosamine are sensitive at lower $\mathrm{pH}(25,27,28)$. Vilar et al. (29) recently reported that exogenously added heparin and HS can indeed be degraded by HUVEC in a reaction that is blocked by NO-synthase inhibitors. Also exogenous NO gas can initiate degradation of heparin and HS in neutral as well as acidic, aqueous solutions. We have observed that extraction of HUVEC with detergent solutions containing sulfamate diminishes degradation of HS and that the endogenous degradation of HS in a transformed vascular endothelial cell-line (ECV) is blocked by NO-synthase inhibitors and by hemoglobin (Mani and Fransson, unpublished data).

\section{Recycling of Glypican and Other Cell-surface Proteins} Our studies on PG production in fibroblasts showed that
く、中間サイズの HS オリゴ糖生成に重要であることを示した (20)。

全血由来血清存在下での培養ヒト血管内皮細胞 (HUVEC) によるPGの生合成についての研究で、我々はラジオアイソトー プレベル化HSPG の自己分解を観察した $(21 、 22)$ 。この分解は、 トリトンX-100、 $4{ }^{\circ} \mathrm{C}$ での抽出の間に起こり、Mr 10-20 kDaの HS 断片を生成する。この分解は、抽出液中にへパリンを添加した

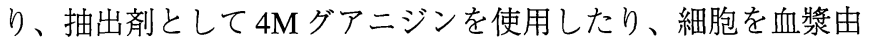
来血清で培養したりすると起こらなかった (22)。温度を上げた り、非密封フラスコでの培養、あるいは抽出培地を薄めたりす るとHS-オリゴ糖の生成が阻害されたり減少する。外部から添 加したHS もまた、全血由来血清の存在下で培養された少量の HUVEC 抽出物と $4{ }^{\circ} \mathrm{C} て ゙$ 培養することで分解された。この分解も また、へパリンの添加や細胞のトリプシンでの事前処理により 起こらなくなった。当初我々は、細胞表面で、血清で活性促進 される、タンパク分解酵素感受性のエンドヘパラナーゼが細胞 膜上 PG 基質の近傍に存在し、この分解を起こしていると考え た。温度の上昇や抽出液の希瀵は、含まれている要素の分散を 引き起こすであろう。グアニジンやへパリンは、その酵素の変 性や活性阻害をそれぞれ引き起こすであろう。しかし、完全密 封フラスコの必要性は、ガス状シグナル分子が存在し非醰素的 過程でHSの分解が起こるということが解るまで、説明ができな かった。

血管内皮細胞は、近くの平滑筋細胞へと分散し、弛緩そし て拡張を起こす酸化窒素 (NO) を生成する (総説、23、24参照)。 NOは、NO-シンターゼにより触媒された反応でアルギニンから 生成され、寿命は短い。NOはへム基により取り上げられ、また 酸化により消費され、亜硝酸 $\left(\mathrm{NO}_{2}^{-}\right)$を生成する。長い間、亜硝 酸 $\left(\mathrm{HNO}_{2}\right)$ が $\mathrm{HS}$ を分解することはよく知られていた (25-27)。

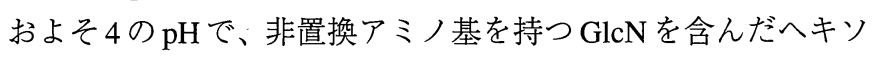
アミン結合を優先的に切断する。一方、 $N$-硫酸化グルコサミン を含んだ結合部位はより低いpHで切断される $(25 、 27 、 28)$ 。ビ ラーらは最近、添加へパリンやHS はNO- シンターゼ阻害剤で 抑制される反応で分解されることを報告した (29)。また外部か らの加えるNOガスは、ヘパリンやHSの分解をを酸性のみなら ず中性水溶液中で起こすことができる。我々も、スルファメー 卜を含んだ界面活性剤を用いたHUVEC抽出液はHSの分解が減 少すること、形質变換血管内皮細胞 (ECV) による内因性 HS の 分解はNO-シンターゼ阻害剤やへモグロビンにより阻害される ことを観察した (Mani と Fransson、未発表デー夕)。

C. グリピカンや他の細胞表面タンパク質の再循環 線維芽細胞による PG 生成についての我々の研究で、サイ 
Trends in Glycoscience and Glycotechnology Vol.10 No.52 (March 1998) pp.81-94

inhibition of de novo protein synthesis by cycloheximide or blocking of transport of newly-made core proteins to the Golgi by brefeldin A prevent incorporation of radiolabelled precursors into approx. $80 \%$ of total PG (30). The residual radiolabelling was exclusively associated with a cell-surface HSPG carrying unusually long HS side-chains. Uhlin-Hansen and Yanagishita (31) found that also rat ovarian granulosa cells produce exclusively HSPG with unusually long side-chains in the presence of brefeldin A. In our study (30), blocking of internalization and degradation of HSPG by suramin or heparin resulted in accumulation of cell-surface HSPG. Combined treatment with brefeldin A and suramin completely abolished PG production suggesting that internalization of resident HSPG and degradation of its HS-chains was a prerequisite for synthesis of new HS-chains. Resynthesis of HS would require recycling of the core protein to the Golgi.

Recycling of cell-surface proteins has been observed in many cell types. Both a short route via endosomes and a longer route via the trans-Golgi or its associated network have been demonstrated (for reviews, see refs. 32, 33). Using a $\mathrm{Ca}^{2+}$-sensitive rat parathyroid cell-line Takeuchi et al. (34) showed that a cell-surface HSPG can recycle between intracellular compartments and the cell-surface. The prion protein, which is a GPIanchored cell-surface protein, cycles between the cell-surface and an endocytic compartment in neuroblastoma cells (35). If a cell-surface located, epithelial sialomucin, episialin, is desialylated and then allowed to recycle, it returns re-sialylated to the cell-surface (36) indicating passage through the transGolgi where sialyltransferases usually reside.

We further characterized the nature of the fibroblast HSPG that appeared to recycle in fibroblasts (37). Suramin, which would impede internalization of HSPG and inhibit degradation of its side-chains, resulted in accumulation of a membrane-bound PG with a core protein of $60-70 \mathrm{kDa}$ (similar to that of glypican) and carrying unusually long HS-chains. After biotinylation of cell-surface proteins in brefeldin A-treated cells, followed by incubation with radiosulphate in the continued presence of the drug (to inhibit glycanation of newly-made core proteins), biotin-tagged radiolabelled PG was detected, indicating the existence of recycling PG species. To radiolabel the core protein of the recycling species, cells were first incubated with $\left[{ }^{3} \mathrm{H}\right]$ leucine or $\left[{ }^{3} \mathrm{H}\right]$ inositol in the presence of suramin and then chased with $\left[{ }^{35} \mathrm{~S}\right]$ sulphate in the presence of brefeldin A. A doubly-labelled, hydrophobic HSPG with a core protein of $60-65 \mathrm{kDa}$ was obtained. The hydrophobic anchor was cleaved off by treatment with $\mathrm{HNO}_{2}$ at $\mathrm{pH} 4$ (deaminative cleavage of the GlcN-Ins bond, see Fig. 1) indicating that the PG was GPI-anchored and thus glypican.

Glypican of fibroblasts and many other cells is usually released from the cell-surface by treatment with PI-PLC (see above). However, the glypican produced in brefeldin A-treated
クロヘキシミドによるタンパク質合成抑制やブリフェルデン $\mathrm{A}$ による新生コアタンパク質のゴルジ体移送妨害により、全PGへ の放射能ラベリングの $80 \%$ が阻害された (30)。この時、異常に 長いHS側鎖を持つ細胞表面HSPGが、独占的に放射能ラベリン グされた。ハンセンと柳下は、ラット胎盤顆粒細胞もまたブリ フェルデン A 存在下で異常に長い糖側鎖を持った HSPG を生成 することを見出した (31)。我々の研究で、スラミンやへパリン によるHSPGの細胞内取り込みや分解の抑制は、細胞表面HSPG の集積を生ずる (30)。ブリフェルデン A とスラミン両者同時処 理はPG生成を完全に阻害する。このことは、細胞表面HSPGの 取り込みと HS 鎖の分解が、新たな HS 側鎖の合成に不可欠であ ることを示している。HSの再合成はコアタンパク質のゴルジ体 への再循環を必要とするのであろう。

細胞表面タンパク質の再循環は多くの細胞種で観察されて いる。エンドソムを通る短ルート、トランスゴルジ体を通る長 ルート、両者を併せ持つネットワークが示されている (総説、 32、33参照)。夕ケウチらは $\mathrm{Ca}^{2+}$ 感受性ラットパラチノイド細胞 株を用いて、細胞表面 HSPG が細胞内部と細胞表面を循環でき ることを示した (34)。GPI-アンカー細胞表面タンパク質である プリオンもまた、神経芽細胞腫において細胞表面と細胞内取り 込み顆粒を循環する (35)。細胞表面に位置するとき、上皮シア ロムチンやエピシアリンは脱シアル酸を起こし再循環する。そ して再度シアル酸が付加され細胞表面に戻る (36)。このことは シアル酸転移酵素が存在するトランス - ゴルジ体を経て循環し ていることを示唆している。

我々はさらに、線維芽細胞で再循環されている HSPG の性 質を検討した (37)。スラミンはHSPG の細胞内取り达みを妨害 し、その側鎖の分解を阻害する。その結果、60-70 kDa（これは グリピカンに類似している)のコアタンパク質と異常に長いHS 鎖を持った膜結合型 PGが集積する。ブリフェルデン A で処理 された細胞を用いて細胞表面タンパク質がビオチン化され、続 いてその細胞がブリフェルデン A 存在下 (新生コアタンパク質 への多糖転移を阻害するため) で放射能ラベル化硫酸とともに 培養されると、ビオチンが付いた放射能ラベル化 PG が検出さ れた。これは PG 種の再循環が起きていることを示唆する。コ アタンパク質の再循環種を放射能ラベルするため、細胞は最初 にスラミン存在下で $\left[{ }^{3} \mathrm{H}\right]$ ロイシンや $\left[{ }^{3} \mathrm{H}\right]$ イノシトールととも に培養され、続いてブリフェルデン $\mathrm{A}$ の存在下で $\left.{ }^{35} \mathrm{~S}\right]$ 硫酸と ともにチェイスされた。60-65 kDaのコアタンパク質を持つ二重 ラベル化疎水性 HSPG が得られた。その疎水性アンカーは $\mathrm{pH} 4$ の $\mathrm{HNO}_{2}$ で分解された (GlcN-Ins 結合の脱アミノ化分解) から、 その PG は GPI-アンカーを持つグリピカンであることが示唆さ れた。

線維芽細胞や多くの他の細胞のグリピカンは、通常PI-PLC の処理により細胞表面から遊離する (上述)。しかし、ブリフェ ルデン A で処理された細胞の合成するグリピカンは、リパーゼ 

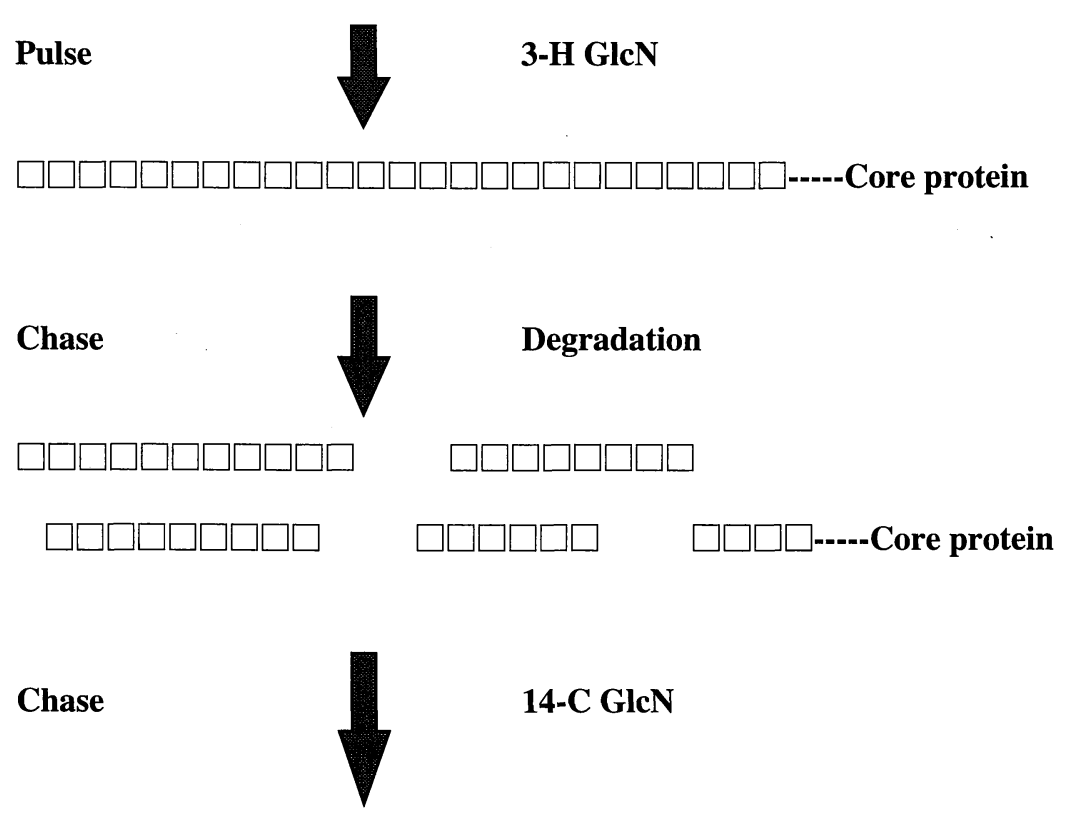

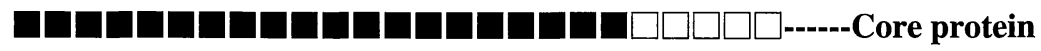

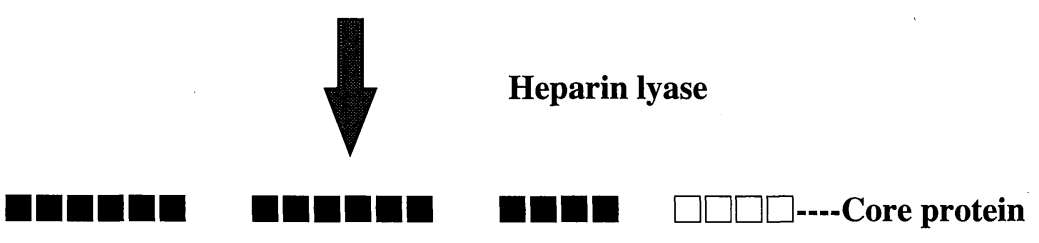

Fig. 4. Outline of pulse-chase experiment and degradation of the product.

cells was resistant to lipase treatment (37). There are several instances where proteins, known to be GPI-anchored by other criteria, exhibit various degrees of resistance to PI-PLC cleavage (see ref. 38 for details). Acylation (usually palmitoylation) of the inositol moiety of the GPI-anchor may confer such resistance. The glypican produced by fibroblasts incorporated $\left[{ }^{3} \mathrm{H}\right]$ palmitate during brefeldin A-treatment (39). Although inositol acylation is believed to take place at an early stage of anchor biosynthesis, it has been detected in alkaline phosphatase after attachment of the GPI-anchor (38). The presence of three acyl groups in the anchor structure would be expected to increase its affinity for certain areas of the lipid bilayer (see Fig. 3). We postulated (39) that newly synthesized glypican reaches the cell-surface where certain forms are inositol deacylated and thus accessible to cleavage by PI-PLC. Glypicans that retain inositol acylation, or deacylated forms that are reacylated, are internalized, their HS-chains are partially degraded, the core protein returns to the Golgi, where new HS-chains are built on the stubs, and the re-processed glypican is recycled back to the cell-surface (Fig. 3).

To distinguish between formation of HS at vacant sites in the core protein, elongation of existing chains or degradation of HS side-chains followed by re-elongation on remaining
作用に侵されない (37)。実際、他の基準でGPI-アンカーである ことが解っているタンパク質に、様々な度合いでPI-PLCによる 分解に抵抗するいくつかの実例がある(詳細 38)。GPI-アンカー のイノシトール部分のアシル化(通例パルミチル化)はそのよう な抵抗性を与える。ブリフェルデン A で処理された線維芽細胞 により合成されるグリピカンは、 $\left.{ }^{3} \mathrm{H}\right]$ パルミチン酸で標識され る (39)。イノシトールのアシル化は、アンカー合成の初期に起 こると思われるが、アルカリフォスファターゼでは GPI-アン カーの付着後にも起きることが知られている (38)。アンカー構 造の中で三つのアシル基の存在により、脂質二重層のある領域 への親和性が増加すると考えられる(図3)。我々は、新規に合 成されたグリピカンは細胞表面に到達すると、あるイノシトー ル部分が脱アシル化され、PI-PLCによる分解を受けると仮説し ている (39)。イノシトールがアシル化されたままあるいは再ア シル化されたグリピカンは、細胞内に取り込まれ、その HS 鎖 は部分的に分解を受け、そのコアタンパク質がゴルジ体に循環 する。そこで新たな HS 鎖が、コアタンパク質の切れ株に合成さ れ、再生したグリピカンが細胞表面に再循環する (図 3)。

コアタンパク質の空いている部位への HS 鎖の生成と、す でに存在している HS 鎖の伸長あるいは HS 側鎖の分解により 


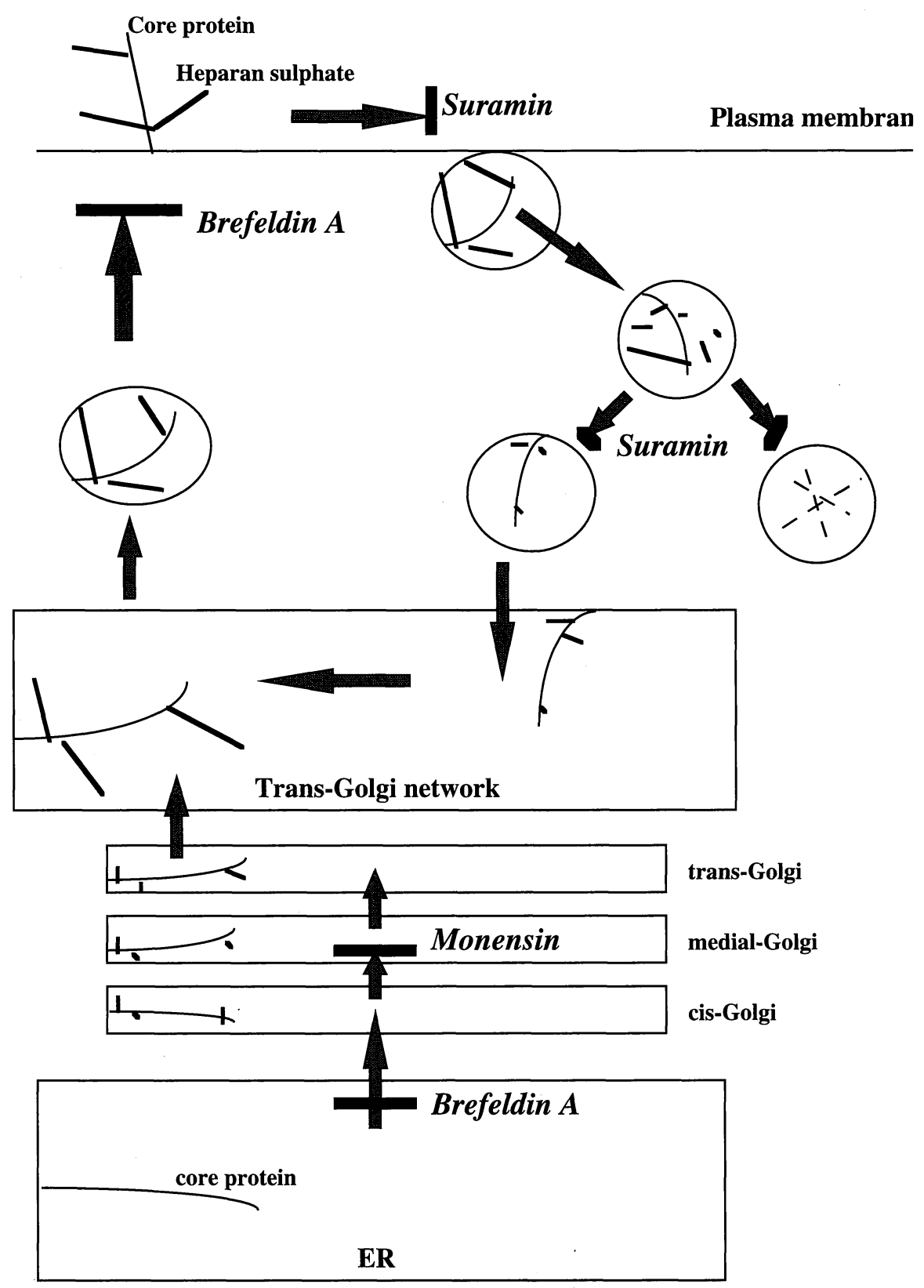

Fig. 5. Model for the synthesis, secretion, endocytosis and recycling of glypican in vascular endothelial cells. Steps inhibited by various drugs are indicated.

stubs, pulse-chase experiments were performed (Fig. 4 and ref. 39). Pulse-labelling was carried out in the presence of suramin or brefeldin A or without drug and chase-labelling was carried out in the presence of brefeldin A. Pulse-labelling with $\left[{ }^{3} \mathrm{H}\right] \mathrm{GlcN}$ followed by chase yielded $\left[{ }^{3} \mathrm{H}\right]$-labelled HS-fragments of $\mathrm{M}_{\mathrm{r}} 20-80 \mathrm{kDa}$ showing that HS side-chains were degraded during recycling. However, some of the chains appeared to remain undegraded. During the chase, cells were allowed to incorporate $\left[{ }^{14} \mathrm{C}\right] \mathrm{GlcN}$ into newly-made HS-chains. The size of the new chains was determined after release from the protein by alkaline scission. The location of $\left[{ }^{3} \mathrm{H}\right] \mathrm{GlcN}$ and $\left[{ }^{14} \mathrm{C}\right] \mathrm{GlcN}$
生じた切り株へのHS 鎖の伸長を区別するため、パルスーチェイ ス実験が行われた (図4と文献39)。パルスラベル化はスラミン あるいはブリフェルデン $\mathrm{A}$ の存在あるいは非存在下で、チェイ スラベル化はブリフェルデン A の存在下で行われた。 $\left[{ }^{3} \mathrm{H}\right] \mathrm{GlcN}$ でのパルスラベル化に続いて、生成した $\mathrm{M}_{\mathrm{r}} 20-80 \mathrm{kDa}$ の $\left[{ }^{3} \mathrm{H}\right] \overline{7}$ ベル化HS 断片をチェイスした結果、HS 側鎖は再循環の間に分 解されていくことが観察された。しかし、糖鎖の一部は分解さ れないままで残るようである。このチェイスの間、細胞は $\left[{ }^{14} \mathrm{C}\right]$ GlcNとともに培養され、新規に合成されたHS鎖をラベルした。 新規糖鎖のサイズは、アルカリ切断によりタンパク質から遊離 
Trends in Glycoscience and Glycotechnology Vol.10 No.52 (March 1998) pp.81-94

relative to the reducing end was determined by treatment with heparin lyase followed by separation of the released outer, nonreducing terminal or internal chain fragments from the chain remnants representing the reducing end and still covalently attached to the core protein. All of the $\left[{ }^{14} \mathrm{C}\right] \mathrm{GlcN}$ was found in protein-free chain fragments and the new chains were not significantly longer than the original ones. We therefore concluded that the new HS-chains were built on the stubs remaining after degradation of the old HS-chains. Depending on the mode of degradation, the non-reducing end of the stubs could either be a glucosamine (after cleavage by endoglucuronidase) or a uronic acid (after enzymatic cleavage by endohexosaminidase or after non-enzymatic deaminative cleavage).

When normal endothelial cells (HUVEC) were radiolabelled and extracted with $4 \mathrm{M}$ guanidine, mostly large HSPG and no HS-fragments were obtained (21), whereas prolonged extraction with Triton X-100 generated HS degradation products (22). In contrast, after radiolabelling of transformed endothelial cells (ECV), both the guanidine and the Triton extracts comprised mainly HS-oligosaccharides and very little intact HSPG (40). However, Northern blot analyses revealed that substantial amounts of glypican mRNA are present in ECV. Treatment with brefeldin A, which in polarized cells inhibits both transport from the RER to the Golgi and endocytosis (41), resulted in a 10-fold accumulation of glypican PG and complete disappearance of the oligosaccharide pool (see also Fig. 5). Suramin combined with brefeldin A had no additional effect, but suramin treatment alone led to partial inhibition of internalization and degradation. Protein-labelled glypican core protein that accumulated during suramin treatment was re-utilized for HSPG-synthesis during chase sulphate-labelling in the presence of brefeldin A. In both fibroblasts and endothelial cells, monensin was without effect on the recycling and re-processing $(39,40)$ indicating that recycling glypican returns to the trans-Golgi.

\section{Co-internalization of Growth Factors, Spermine, Genes, Viruses and Microbes}

Cell-surface HSPG have been implicated in binding and activation of a number of extracellular proteins which is described in other chapters. Binding and activation of members of the fibroblast growth factor (FGF) family has been studied in great detail. Of relevance to this review are observations that cell surface-associated basic FGF can be released by treatment with PI-PLC (42) and that HS-chains carried by glypican can bind several members of the FGF family with low affinity and support FGF-interaction with the high-affinity signalling receptor (43). Internalization of basic FGF via a heparin-sensitive pathway, involving a low-affinity receptor, i.e. HSPG, has been demonstrated in CHO cells lacking the signalling receptor (44). Inhibition of sulphation of HS or enzymatic removal of cell-
させた後、決定した。還元末端に対する $\left[{ }^{3} \mathrm{H}\right] \mathrm{GlcN}$ と $\left[{ }^{14} \mathrm{C}\right] \mathrm{GlcN}$ の結合位置は、ヘパリンリアーゼ処理後還元末端に残る糖残余 を用いて、遊離した非還元末端側あるいは糖鎖内部からの糖鎖 断片とコアタンパク質に共有結合していた糖鎖断片を区分する ことで決定した。 $\left.{ }^{14} \mathrm{C}\right] \mathrm{GlcN}$ のすべてはタンパク質を含まない 糖鎖断片に含まれており、新規の糖鎖は、オリジナルなものに 比べてそれほど長くはなかった。したがって我々は、新規のHS は古いHS側鎖が分解された後、その切り株に結合すると結論す ることができた。分解の様式により、その切り株の非還元末端 はグルコサミン (エンドグルクロニダーゼにより分解された時) あるいはウロン酸 (エンドヘキソースアミニダーゼあるいは非 酵素的脱アミノ化により分解された時) のどちらかを採ること になる。

正常な内皮細胞 (HUVEC) が放射能ラベルされ、 $4 \mathrm{M}$ グア ニジンで抽出された時、ほとんどが大きな HSPGである HS- 糖 鎖断片は得られない (21)、しかしトリトンX-100での長い抽出 はHS の分解生成物を生ずる (22)。反対に形態変異化した内皮 細胞 $(\mathrm{ECV})$ を放射能ラベルした後、グアニジンあるいはトリト ン抽出すると、ほんどがHS-オリゴ糖で完全な HSPG はほとん ど得られない(40)。しかしながら、ノーザンブロット分析から、 グリピカン mRNAの相当な量が ECV に存在していることが示 されている。極性細胞をブリフェルデン A で処理すると、RER からゴルジ体への移送とエンドサイトーシス両者が抑制され (41)、その結果 10 倍のグリピカン PG が集積され、オリゴ糖鎖 の生成はほとんど消失する (図 5)。ブリフェルデン A とともに スラミンを添加しても付加的効果はないが、スラミン単独では 細胞内取り込みや分解の部分的阻害が見られた。スラミン処理 の間集積されたラベル化グリピカンコアタンパク質は、ブリ フェルデン A 存在下のチェイス硫酸ラベル化に際し HSPG 合成 に再利用される。線維芽細胞と内皮細胞両者でモネンシンは、 再循環や再合成に効果がなかった $(39 、 40)$ 。のことは再循環す るグリピカンはトランスーゴルジ体に戻ることを示唆している。

D. 増殖因子、スペルミン、遺伝子、ウィルス、微生物の細胞 内取り込み

他にも記述されているように、細胞表面 HSPG は多くの細 胞外タンパク質と結合し活性化にも関与している。線維芽細胞 増殖因子(FGF)のメンバーとの結合や活性化は詳細に研究され てきた。これら FGFについてのいくつかの知見は、このレ ビューにも関連している。すなわち細胞表面結合塩基性FGFは PI-PLCの処理により遊離させることができる (42)。またグリピ カン上の HS 鎖はFGFファミリーのいくつかのメンバーと低親 和性を持って結合し、FGF と高親和性シグナル伝達レセプター との相互作用を維持する (43)。HSPG である低親和性レセプ ターを含んだへパリン感受性行程による FGF の細胞内取り込み がシグナル伝達レセプターを持たない $\mathrm{CHO}$ 細胞で実証された (44)。HS の硫酸化抑制や細胞表面 HS の酵素分解は FGF 取り込 
surface HS inhibited FGF uptake. Transforming growth factor$\beta$, which stimulates HSPG synthesis, increased internalization of basic FGF by smooth muscle cells (45). The HSPG involved was characterized by a high turnover. Immunocytochemical studies have shown that basic FGF endocytosed in BHK cells is addressed to caveolae, and then sequentially detected in early endosomes, late endosomes and finally lysosomes (46). Interestingly, pretreatment of the cells with PI-PLC reduced the overall proportion of FGF bound to the cell-surface but did not inhibit its presence in caveolae, raising the possibility that FGF was bound to an PI-PLC resistant form of glypican residing in caveolae. The fate of the HSPG co-internalized with FGF is not known.

Polyamines, such as spermine, are essential for cell growth and differentiation (for references, see ref. 47). Polyamine pools are maintained by endogenous synthesis and by uptake from the environment. The cationic polyamines bind electrostatically to polyanionic molecules. Interactions with DNA and RNA have received most of the attention. We have shown (47) that spermine binds to highly sulphated regions in HS and that HS can be subfractionated on spermine affinity columns. HS variants with high affinity for spermine have high antiproliferative activity. However, there was no obvious correlation between affinity for spermine and sulphate content, suggesting sequence-specific interactions. We have recently obtained evidence indicating that cell-surface HSPG is involved in spermine uptake (48).

As polyamines and other positively charged molecules, such as polylysine, form complexes with DNA, they can be used as non-viral transfection agents in gene transfer/gene therapy research (for references, see ref. 49). Optimal uptake requires an excess of cation over anion, giving the complex a net positive charge. Mieslik \& Baldeschwieler demonstrated that polylysine-DNA complexes (charge ratio 3:2) enter cells via binding to cell-surface HSPG (49). Addition of heparin or HS, blocking of sulphation by chlorate or enzymatic removal of cell-surface HS, all inhibited gene delivery. Transfection of mutant, PG-deficient $\mathrm{CHO}$ cells was 53 times lower than of wild-type cells.

Cell-surface HSPG also play a role in viral and microbial invasion. An envelope glycoprotein of herpes simplex virus binds to HS and promotes both adherence and virus-cell fusion (50). Many microbes appear to use cell-surface HS for binding, e.g. Helicobacter pylori (51). The role of HS in the entry of the intracellular pathogen Listeria monocytogenes was recently documented (52). Pretreatment of bacteria with HS and enzymatic removal of HS from target cells, impaired adhesion and invasion. Mutant, PG-deficient CHO cells, internalized fewer bacteria than did wild-type cells.
みを阻害する。HSPG の合成促進をするトランスフォーミング 増殖因子 $\beta$ は、平滑筋細胞による塩基性 FGFの取り込みを増加 させる (45)。これに含まれるHSPG は回転率が高い特徴を持っ ている。免疫組織化学的研究で、BHK細胞により取り込まれた 塩基性 FGF は、まず小胞へ向かい、続いて初期エンドソーム、 さらに後期エンドソーム、最終的にリソゾームへと移行してい く(46)。面白いことに、細胞を PI-PLCで前処理すると FGF の 全体量は減少するが、小胞への移行を阻害しない。このことは、 FGF は小胞に存在する PI-PLC 抵抗型グリピカンとも結合する 可能性を示唆している。FGFとともに取り込まれたHSPGのそ の後の運命はまだ知られていない。

スパルミンのようなポリアミンは、細胞増殖や分化に重要 である (文献47)。ポリアミンは内因的合成と外部からの取り込 みにより維持されている。陽電荷を帯びたポリアミンはポリア ニオン分子と静電的に結合する。DNA や RNA との相互作用も 高い注目を集めている。我々は、スパルミンはHS の高硫酸化ド メインと結合し、スパルミンアフィニティーカラムでHSを分別 できることを示した (47)。スパルミンと高親和性を持つ HS 種 は高い細胞增殖抑制活性を有している。しかし、スパルミンと の親和性と硫酸含量との明らかな相関がないことから、配列特 異的相互作用であることが示唆される。我々は最近、細胞表面 HSPG がスパルミン取り込みに関与していることを示す確証を 得た (48)。

ポリアミンやポリリジンのような他の陽電荷分子は、DNA と複合体を形成し、遺伝子導入や遺伝子治療研究のための非 ウイルス型遺伝子導入試薬として利用することができる (文献 49)。最適の取り込みには陰電荷に対して過剩な陽電荷を与え て、その複合体全体を陽電荷にする必要がある。ミースリック とボールデシュウーラは、ポリリジン -DNA 複合体は細胞表面 HSPG との結合を経て細胞内へ取り込まれることを示した(49)。 ヘパリンやHSの添加、クロレートによる硫酸化阻害、細胞表面 HSPG の酵素消化はみな遺伝子導入を阻害する。PG 欠損 CHO 変異株への遺伝子導入率は、正常細胞の場合と比べて、53倍低 下した。

細胞表面 HSPG はまた、ウイルスや微生物感染においても 役割を演じている。単純へルペスのエンベロップ糖タンパク質 は、HS と結合し、接着やウィルス - 細胞融合を促進する (50)。 ヘリコバクターピロリ菌のような多くの微生物も、結合のため に細胞表面 HS を利用している(51)。リステリア菌の細胞内侵 入における HS の役割が、最近記述された (52)。バクテリアを HS で事前処理したり、標的細胞HS の酵素消化は、接着や感染 を阻害する。PG 欠損 CHO 変異株は、正常細胞と比べはるかに 少ないバクテリアしか細胞内に取り込まない。 


\section{E. Transcytosis of Lipoproteins and Lipoprotein Lipase}

The vessel wall serves as a barrier between blood and extravasal tissue. By a process known as transcytosis the vascular endothelial cells can regulate passage of physiologically important molecules across this barrier. Sterol-binding agents that disrupt the formation of caveolae inhibit transcytosis of insulin and albumin but not clathrin-mediated endocytosis destined for degradation (53). Lipoprotein lipase (LPL) hydrolyzes triglycerides in plasma lipoproteins while bound to HSPG on the lumenal side of the endothelium (for review, see ref. 54). However, the enzyme is synthesized by adipocytes and myocytes and must traverse the endothelium from the outside to reach its final destination. Saxena et al. $(55,56)$ demonstrated that cell-surface HSPG is an endothelial LPL receptor and that it mediates internalization and recycling of LPL. Misra et al. (57) have characterized an adipocyte-derived, glypicanlike HSPG with affinity for lipoprotein lipase.

Substrates for LPL, such as the lipoproteins LDL and VLDL, also bind to cell-surface HSPG, in a reaction that is enhanced by the presence of LPL $(58,59)$. A slow uptake of lipoproteins, co-internalized with HSPG, occurs in addition to the rapid classical LDL receptor recycling system. A binding site for HS in lipoproteins appears to be located to apolipoprotein $\mathrm{E}$ $(60)$.

\section{F. Conclusions and Speculations}

HS-chains carried by glypican can be transported selectively to the apical surface of polarized cells. They also have the option of being concentrated to caveolae. Wherever they are, they may be subject to controlled degradation, either enzymatically or non-enzymatically, either at the cell surface or after internalization to an endosomal compartment. The fate of the HS degradation products is unclear but they may enter the cytosol via some carrier-system and from there they may even reach the nucleus. The growth-regulating activity of such HS-fragments may be either supportive or suppressive, depending on the structural features. Internalization of glypican may result in cotransport of a variety of molecules with cationic properties bound to its polyanionic HS-chains. Recycling of glypican via the Golgi provides an opportunity for synthesis of new HS chains. Thereby cells can continually alter the molecular design of HS in response to external or internal factors. Such modifications of the new HS chains may lead to different binding patterns for various cytokines, peptide growth factors, lipoproteins, enzymes and polyamines.

\section{Acknowledgements}

Our own work cited in this review was supported by the Swedish Medical Research Council, the Swedish Cancer Foundation and the Swedish Society of Medicine as well as the Bergvall, Kock, Nilsson, Persson, Wiberg and Österlund Foundations.
E .リポタンパク質とリポタンパク質リパーゼの壁転移 (Transcytosis)

血管壁は、血液と脈管外組織間の障壁として機能している。 血管内皮細胞はトランスサイトーシスと呼ばれる作用で、生理的 に重要な分子がこの障壁を透過するのを制御している。小胞の形 成を妨害するステロール結合試薬は、インスリンやアルブミンの トランスサイトーシスを阻害するが、タンパク質分解を生ずるク ラスリン依存性エンドサイトーシスは阻害されない (53)。リポ タンパク質リパーゼ (LPL) は、血管内腔の HSPG と結合した血 漿性リポタンパク質のトリグリセリドを加水分解する (総説、 54)。しかしその酵素は、脂肪細胞や筋細胞で合成され、最終目 的地である血管内皮細胞内腔側へ到達するために運ばれなければ ならない。サクセナらは、細胞表面 HSPG は内皮LPLレセプター であり、それがLPL の細胞内取り込みや再循環を媒介すること を示した (55、56)。ミスラらは、リポタンパク質リパーゼと親 和性を有する脂肪細胞由来グリピカン様HSPGの特性を明らかに した (57)。

リポタンパク質、LDLやVLDLのようなLPLの基質もまた、 細胞表面 HSPG と結合する。この結合はまた、LPLの存在で促進 される $(58 、 59) 。 H S P G$ ともにリポタンパク質がゆっくりと細 胞内へ取り込まれていく現象は、昔から知られている迅速な LDL 再循環システムとは独立的なものでる。リポタンパク質の HS 結合部位はアポリポタンパク質 Eにあると考えられる (60)。

\section{F．結論と展望}

グリピカンの HS 側鎖は選択的に極性細胞の頂面に運ばれ る。それらはまた、小胞に移行するかどうかの選択をするのであ る。それらがどこに存在しようとも、細胞表面であるいは細胞内 に取り込まれた後エンドソム内で、酵素的あるいは非酵素的に制 御された分解を受ける。HS 分解生成物の運命は明らかではない が、ある運搬システムに乗って細胞質内の入り、細胞核へ到達す ることさえできるかもしれない。HS断片の細胞増殖制御活性は、 構造の特徵により促進的であったり、抑制的であったりする。グ リピカンは、ポリアニオンに結合する陽性特性を持った様々な分 子とともに細胞内へ取り込まれる。グリピカンがゴルジ体を経て 再循環することで、新たにHS 鎖が合成される。それにより、細 胞は連続的に内外の因子に応じてHSの分子デザインを変えるこ とができる。そのような新しいHS 鎖の修飾は、様々なサイトカ イン、ペプチド増殖因子、リポタンパク質、酵素類、ポリアミン との異なる結合様式を生み出しているのである。

\section{防衛医科大学校防衛医学研究センター医療工学部門}

石原 雅之 訳 


\section{References}

1. Kraemer, P.M., and Tobey, R.A. (1972) J. Cell Biol. 55, 713-717

2. Ishihara, M., Fedarko, N.S., and Conrad, H.E. (1987) J. Biol. Chem. 262, 4708-4716

3. Carey, D.J., and Evans, D.M. (1989) J. Cell Biol. 108, 1891-1897

4. Yanagishita, M., and McQuillan, D.J. (1989) J. Biol. Chem. 264, 17551-17558

5. Schmidtchen, A., Sundler, R., and Fransson, L.-Å. (1990) Glycoconjugate J. 7, 563-572

6. Udenfriend, S., and Kodukula, K. (1995) Annu. Rev. Biochem. 64, 563-591

7. David, G., Lories, V., Decock, B., Marynen, P., Cassiman, J.-J., and Van den Berghe, H. (1990) J. Cell Biol. 111, $3165-3176$

8. Simons, K., and Ikonen, E. (1997) Nature 387, 569-572

9. Brown, D.A., and Rose, J.K. (1992) Cell 68, 533-544

10. Mertens, G., Van der Schueren, B., Van den Berghe, H., and David, G. (1996) J. Cell Biol. 132, 487-497

11. Rothberg, K.G., Ying, Y., Kolhouse, J.F., Kamen, B.A., and Anderson, R.G.W. (1990) J. Cell Biol. 110, 637-649

12. Anderson, R.G.W. (1993) Proc. Natl. Acad. Sci. USA 90, 10909-10913

13. Yanagishita, M. (1992) J. Biol. Chem. 267, 9505-9511

14. Oldberg, Å., Kjellén, L., and Höök, M. (1979) J. Biol. Chem. 254, 8505-8510

15. Kjellén, L., Pertoft, H., Oldberg, Å., and Höök, M. (1985) J. Biol. Chem. 260, 8416-8422

16. Nakajima, M., Irimura, T., and Nicolson, G.L. (1988) J. Cell. Biochem. 36, 157-167

17. Bame, K.J. (1993) J. Biol. Chem. 268, 19956-19964

18. Hovingh, P., Piepkorn, M., and Linker, A. (1993) Eur. J. Biochem. 211, 771-779

19. Schmidtchen, A., and Fransson, L.-Å. (1994) Eur. J. Biochem. 223, 211-221

20. Bai, X., Bame, K.J., Habuchi, H., Kimata, K., and Esko, J.D. (1997) J. Biol. Chem. 272, 23172-23179

21. Lindblom, A., Carlstedt, I., and Fransson, L.- $\AA$. (1989) Biochem. J. 261, 145-153

22. Lindblom, A. (1991) Doctoral Dissertation, Lund University

23. Knowles, R.G., and Moncada, S. (1992) Trends Biochem. Sci. 17, 399-402

24. Wink, D.A., Grisham, M.B., Mitchell, J.B., and Ford, P.C. (1996) Methods Enzymol. 268, 12-31

25. Lagunoff, D., and Warren, G. (1962) Arch. Biochem. Biophys. 99, 396-400

26. Cifonelli, J. (1968) Carbohydr. Res. 8, 233-242

27. Shively, J.E., and Conrad, H.E. (1976) Biochemistry 15, 3932-3942

28. Lindahl, U., Bäckström, G., Jansson, L., and Hallén, A. (1973) J. Biol. Chem. 248, 7234-7241

29. Vilar, R.E., Ghael, D., Li, M., Bhagat, D.D., Arrigo, L.M., Cowman, M.K., Dweck, H.S., and Rosenfeld, L. (1997) Biochem. J. 324, 473-479

30. Fransson, L.-Å., Karlsson, P., and Schmidtchen, A. (1992) Biochim. Biophys. Acta 1137, 287-297

31. Uhlin-Hansen, L., and Yanagishita, M. (1993) J. Biol. Chem. 268, 17370- 17376

32. Farquhar, M.G. (1985) Annu. Rev. Cell Biol. 1, 447-488

33. Trowbridge, I.S., Collawn, J.F., and Hopkins, C.R. (1993) Annu. Rev. Cell Biol. 9, 129-161

34. Takeuchi, Y., Yanagishita, M., and Hascall, V.C. (1992) Arch. Biochem. Biophys. 298, 371-379

35. Shyng, S.-L., Huber, M.T., and Harris, D.A. (1993) J. Biol. Chem. 268, 15922- 15928

36. Litvinov, S.V., and Hilkens, J. (1993) J. Biol. Chem. 268, 21364-21371

37. Fransson, L.-Å., Edgren, G., Havsmark, B., and Schmidtchen, A. (1995) Glycobiology 5, 407-415

38. Wong, Y.W., and Low, M.G. (1994) Biochem. J. 301, 205-209

39. Edgren, G., Havsmark, B., Jönsson, M., and Fransson, L.-Å. (1997) Glycobiology 7, 103-112

40. Wiik, P., Mani, K., Belting, M., Edgren, G., and Fransson, L.-Å. (1997) Glycobiology (submitted)

41. Uhlin-Hansen, L., and Yanagishita, M. (1995) Biochem. J. 310, 271-278

42. Bashkin, P., Neufeld, G., Gitay-Goren, H., and Vlodavsky, I. (1992) J. Cell. Physiol. 151, 126-137

43. Bonneh-Barkay, D., Shlissel, M., Berman, B., Shaoul, E., Admon, A., Vlodavsky, I., Carey, D.J., Asundi, V.K., Reich-Slotky, R., and Ron, D. (1997) J. Biol. Chem., 272, 12415-12421

44. Roghani, M., and Moscatelli, D. (1992) J. Biol. Chem. 267, 22156-22162

45. Berrou, E., Quarck, R., Fontenay-Roupie, M., Lévy-Toledano, S., Tobelem, G., and Bryckaert, M. (1995) Biochem. J. 311, 393-399

46. Gleizes, P.-E., Noaillac-Depeyre, J., Dupont, M.-A., and Gas, N. (1996) Eur. J. Cell Biol. 71, 144-153

47. Belting, M., Havsmark, B., Jönsson, M., Persson, S., and Fransson, L.-Å. (1996) Glycobiology 6, 121-129

48. Belting, M., Persson, S. and Fransson, L.-Å. (1997) J. Biol. Chem. (submitted)

49. Mislick, K.A., and Baldeschwieler, J.D. (1996) Proc. Natl. Acad. Sci. USA 93, 12349-12354

50. Herold, B.C., Visalli, R.J., Susmarski, N., Brandt, C.R., and Spear, P.G. (1994) J. Gen. Virol. 75, 1211-1222

51. Ascencio, F., Fransson, L.-A., and Wadström, T. (1993) J. Med. Microbiol. 38, 240-244

52. Alvarez-Domìnguez, C., Vásquez-Boland, J.-A., Carrasco-Marìn, E., Lòpez- Mato, P., and Leyva-Cobián, F. (1997) Infect. Immun. 65, 7888

53. Schnitzer, J.E., Oh, P., Pinney, E., and Allard, J. (1994) J. Cell Biol. 127, 1217-1232

54. Olivecrona, T. and Bengtsson-Olivecrona, G. (1990) Curr. Opinion Lipid. 1, 222-230

55. Saxena, U., Klein, M.G., and Goldberg, I.J. (1990) J. Biol. Chem. 265, 12880-12886

56. Saxena, U., Klein, M.G., and Goldberg, I.J. (1991) J. Biol. Chem. 266, 17516-17521

57. Misra, K.B., Kim, K.C., Cho, S.Y., Low, M.G., and Bensadoun, A. (1994) J. Biol. Chem. 269, 23838-23844

58. Eisenberg, S., Sehayek, E., Olivecrona, T., and Vlodavsky, I. (1992) J. Clin. Invest. 90, 2013-2021

59. Mulder, M., Lombardi, P., Jansen, H., van Berkel, T.J.C., Frants, R.R., and Havekes, L.M. (1993) J. Biol. Chem. 268, 9369-9375

60. Ji, Z.S., Brecht, W.J., Miranda, R.D., Hussain, M.M., Innerarity, T.L., and Mahley, R.W. (1993) J. Biol. Chem. 268, 10160-10167 


\section{Profile of the Author}

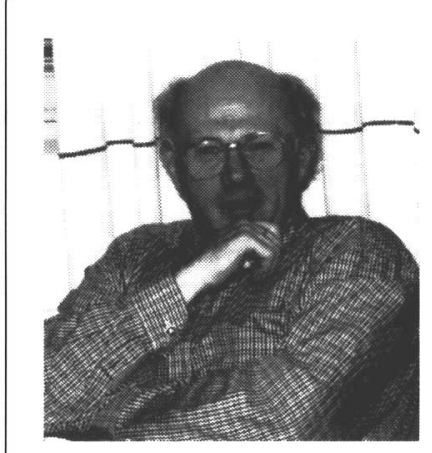

Lars-Åke Fransson

Was admitted to

Medical School, Lund University in 1961. He performed his $\mathrm{PhD}$ thesis work in the Department of Biochemistry, University of Chicago, under the guidance of Dr. Lennart Rodén between 1966-68. In this study the copolymeric structure of dermatan sulfate (DS) was demonstrated. A combined $\mathrm{MD} / \mathrm{PhD}$ was received from Lund University in 1968. Between 1968-70 Dr Fransson held a postdoctoral position in the Department of Medical and Physiological Chemistry, Lund University (Head: Prof Sven Gardell) and started to work on the biosynthesis of IdoUA. In 1970 he was appointed to a Lectureship (Reader/Assoc.
Prof.) in medical and physiological chemistry with considerable teaching responsibilities. The research activities included epimerization of GlcUA to IdoUA, biosynthesis and secretion of proteoglycans and self-association via their copolymeric chains, such as DS and heparan sulphate (HS). The latter area was specifically studied during a stay as Visiting Professor in the Department of Biological Sciences, Lancaster University, U.K. between 197678. During the 80 s and 90 s the work has mainly been focussed on isolation and characterization of different proteoglycans from cultured cells, the growth-inhibitory effects of glycans, development of glycan sequencing methods, effects of cytokines and growth factors and various drugs that inhibit intracellular progression, internalization and degradation. The latter aspect is expounded in the accompanying review. In 1992 Dr Fransson was appointed Full Professor in Cell Biology. 